\title{
Character Building through School Culture Development in the Senior High School of Panca Budi Medan
}

\author{
Candra Wijaya ${ }^{1}$, Manshuruddin ${ }^{2 *}$, Zulham Effendi ${ }^{3}$ \\ ${ }^{1}$ Postgraduate, Universitas Islam Negeri Sumatera Utara, Medan, Indonesia \\ ${ }^{2}$ Faculty of Islamic and Humanities, Universitas Pembangunan Panca Budi, Medan, North Sumatera, Indonesia \\ ${ }^{3}$ Sekolah Tinggi Agama Islam As-Sunnah, Medan, Indonesia
}

DOI: $\underline{10.36348 / \mathrm{sjhss} .2020 . \mathrm{v} 05 \mathrm{i} 01.002}$

| Received: 15.01 .2020 | Accepted: 22.01.2020 | Published: 27.01 .2020

*Corresponding author: Manshuruddin

Abstract

This research aims to analyse the efforts of the character building of school culture based in Senior High School of Panca Budi Medan as well as supporting factors and the termination. This research uses qualitative method with the research site, namely Senior High School of Panca Budi Medan. As for the data analysis techniques using interactive analysis Model Milles \& Huberman is through data reduction, data display and data verification/withdrawal conclusion. Determination of the subject using snowball sampling technique. Data collection techniques using non-participatory observation, in-depth interviews and documentation studies. From the results of the study obtained a number of schools culture that became the frame and base of character formation of students in Senior High School of Panca Budi Medan, namely; 1) Religious culture, 2) honest culture, 3) clean culture and energy saving, 4) Culture of discipline. The supporting factor for student character formation in Senior High School of Panca Budi is 1) family factors that emphasize the role of parents in strengthening the habituation of good behavior to the child of what results have been received in school; 2) The teacher's factors emphasize the teacher's involvement in shaping the student's character through education, mentoring, and the example; 3 ) environmental factors that include the school environment and community. In supporting the character building of the students, the school constantly engineered a conducive environment so that what the students see, hear, and feel are supportive of character building. The Community's environmental support is seen from conduciveness the daily behaviour of local residents in line with the values of characters obtained by students from the school; 4) Learners ' factors that appear to be high in enthusiasm and curiosity in understanding the importance of character value inherent in every activity that cultures in school. The inhibitory factor of students ' character formation in Senior High School of Panca Budi is: 1) family factor, occurring in elderly people who are too busy working; 2) teacher factors, more to educators who have not given the students an example; 3) Environmental factors, this occurs in the environment of learners who are partially living in a residential that is individualist and free in association; 4) Student factors, diversity of students ' cognitive development and emotion, especially students who are less able to understand the values embodied in school culture.

Keywords: Formation, Character, Student, Culture, School, Panca Budi.

Copyright @ 2020: This is an open-access article distributed under the terms of the Creative Commons Attribution license which permits unrestricted use, distribution, and reproduction in any medium for non-commercial use (NonCommercial, or CC-BY-NC) provided the original author and source are credited.

\section{INTRODUCTION}

This research seeks to analyse best practices from the character building of school culture based students in Senior High School of Panca Budi Medan. The basic assumption behind this research departs from the failure of the school's formal education in implementing the values of character education to learners who have an impact on the low moral quality of the nation's children. Declining moral quality in recent years can be proved by the news that many are talked about on television, newspapers, social media, and various other media concerning the moral deviations of students who are very concern.

Case-by-case demoralization that occurs among students such as brawl, free association, drugs, beating teachers, bullying, and other negative behaviors is made to us that there is a need for improvement in the system of Students in the school's formal education. The following is presented by one of the delinquency of teenagers occurring in Indonesia, which is a free sex behavior that has been increasingly rampant in some major cities in Indonesia. Among them Jakarta 58\%, in 
Surabaya pre-marital sex reached $54 \%$, followed by Medan as much as $52 \%$, and Bandung as much as 47 percent[1].

From the example data of adolescent delinquency that the status of the student can prove that there has been a moral shift in our country. The moral crisis that Indonesia has experienced today is at a very alarming point, such as, honesty, polite, genuine nature, and the instantaneous responsibility is replaced with immoral values. Therefore, juvenile delinquency is a weak indicator of the character education in Indonesia, where education is an important factor in building moral fortresses and national characters.

Said Agil Husein In response to the phenomenon of moral crisis with the view that today the world of education is facing severe examinations and challenges because education is the most important factor in preparing qualified human resources and Immoral. Educational thinkers call for sensible intelligence to be followed by moral intelligence [2].

Education not only relies on, prioritizing achievement and transferring a number of sciences, but education is very important in developing the discipline and planting of students ' personality values. So that resulted from the school system to be human that has a good character.

Character education is a national movement to create a school that builds a young generation that is ethical, responsible, and caring for others. Character education is also not merely to teach which is true and which is wrong but to educate children to make decisions wisely and to practice in everyday life, so that they can give Positive contribution to society [3].

The development of character values in students must be through examples and in the surroundings. If there is good communication between the family, school and community, it will make it easier to develop the character in the child, because the child character can be formed by habituation, direction, research, coaching, and Supportive environment. Therefore, planting or character education for children becomes very important.

In order for learners to have a noble character according to religious norms, laws, manners, cultures, and customs, therefore, the school is required to play a more adequate role and responsibility to embed, develop, build, and Help students shape their character with good value [4].

One of the scopes of character education that greatly supports the implementation of character education progress is the school culture [5]. The school culture is built to create and embed character values for all the citizens of the school, including creating a character education program or policy, forming a school culture, and communicate it to all of the school, maintaining character values, and respecting the achievement of each party in the school.

School culture strongly supports the success of character education programs. However, not all school cultures support achieving maximum character education. Because a negative culture in school culture can impede the implementation of character education in schools such as the number of empty hours, disobedient in the execution of the code of conduct, and so on. This suggests that school culture has a major influence on the character building process of students.

It is understandable that character education also has a role to be part of shaping the school culture. Therefore, the establishment of student character through school culture becomes absolutely needed by the school to create a conducive school culture and facilitate the planting of character values in the students. The process becomes more effective when it is applied to individual students, because it is necessary as a foundation of the student's character in the future later.

\section{RESEARCH METHOD}

This research is qualitative field research. The reason is that in this study took the cultural objects of the school in Senior High School of Panca Budi Medan as a frame and base in the application of character education. In this case qualitative research involves an approach of naturalistic interpretation and study of the objects in its natural environment, trying to make or interpret the phenomenon in the point of view of the meanings given by the community to them [6].

Qualitative in question is a form of research procedure that generates descriptive written data obtained from the resource, either through observation or from interviews to sources of informant that has been used as the subject in the study. [7] Observation is conducted systematically with standard procedures [10]. This research is not independent of the observations seen and heard and then analyzed to be held in order to obtain the results as objectively as possible [8]. In the event of interviews there are two people more behave in accordance with their respective status and role [9].

The primary data referred to here is the data obtained from the combination of observation participating and unstructured interviews against some key persons (key person), namely the principal, officers, teachers and students in the Senior High School of Panca Budi Medan. This interview was conducted indepth regarding the implementation of character education based on school culture in Senior High School of Panca Budi and its supporting factors and the retardant. The secondary data in question is the library resources that discuss the school institutions and the 
character education paradigms applied therein. The data of the library can be in the form of books, journals, articles, academic papers, etc.

This research is a descriptive analysis, aiming to create a systematic, factual, and accurate depiction or painting of the facts, properties and relationships between the sub-objects being examined. Data analysis is an effort to systematically find and organize records of observations, interviews, and documentation to improve understanding of objects and present as findings for others. The data analysis techniques are done through the data reduction phases, data display and data verification/withdrawal conclusions.

\section{RESEARCH FINDINGS AND DISCUSSION A glimpse of the HIGH School of Panca Budi Medan}

The college stood since the year 1961, and initially there is only one level that is managed by the College of High School Agriculture (SPMA/SPP). The college founded by the students ' Chairman, Prof. DR. H. Kadirun Yahya [10] who routinely conducts religious activities (Zikrullah) on the campus of Panca Budi, so the desire to school their children in Panca Budi Medan. Since its inception in 1961 to 1997, the Panca Budi College has grown naturally and socially, because the focus of the foundation at the time was to foster religious activities.

In the year 1997 based on the instruction of the general chairman of the Foundation so that the education institution is managed with the professional, the instruction is implemented well by the foundation board is characterized by the formation of a new school unit namely Vocational High School Technology and Industry, Senior High School ofs Panca Budi Medan and Vocational High School business and management.

The Senior High School of Panca Budi Medan already has operational permit from the Ministry of National Education with Decree of the Minister of Education Number: 420/886/Dikur/2014 dated 30 January 2014 has obtained received a from the National School received agency. The Status of Senior High School of building Panca Budi Medan is Yayasan Prof. Dr. H. Kadirun Yahya. Currently, Senior High School of Panca Budi Medan has two majors namely Natural Sciences (IPA) and Social Sciences (IPS).

\section{Vision, Mission, Senior High School of}

\section{A. Vision}

To prepare a superior generation who has character, faith, caring environment and competitiveness

\section{B. Mission}

1) Implement the process of teaching and learning activities effectively and optimally to give birth to the superior generation.
2) Able to communicate well with international language.

3) Foster a social and environmental attitude.

4) Conduct regular religious activities to produce students with character.

\section{Values}

In implementing the development of education, Senior High School of Panca Budi continuously improves its appearance and performance in line with the development of community values. In relation to this, the school's Panca Budi prioritizes the following values:

\section{1) Spirituality}

The foundation of values to God and humanity is a major prerequisite for forming human believers, science and work through the Method Zikirullah by adopting 7 basic Values Foundation, namely:

a) To maintain the purity of creed and carry out the sharia (prayer, dhikr).

b) Grateful, fond and not complaining.

c) Humble, modest, as is, forgiving, unoffended, and not angry.

d) Think positively, prejudiced and do not use.

e) To do good, to change and to be inspiring.

f) Empathize and provide solutions, not criticizing or reproach.

g) Adherence to leaders and regulations.

\section{2) Achievements}

SMA Panca Budi sees the quality of the pond is an achievement that must be able to be demonstrated and applied directly in the form of the absorption of the investigation in state universities, and entrepreneurial spirit.

\section{3) Integrity}

The strength of the learning organization is the power of integrity to individual intellectuality that is rational is the main requirement for the advancement of High school education organization Panca Budi.

\section{4) Positive Attitude}

SMA Panca Budi sees the success of the education process determined by how the application's ability is positive mental attitude in realizing the objectives of high school education organization Panca Budi.

\section{5) Competition $\&$ adaptation}

The situation of socio-cultural and technological developments and science should be able to be addressed as an issue to be found solutions. By human builders who have the ability to adapt, mentality and competitiveness are high. 


\section{6) Team Work}

Contributions between individual individuals that are able to be realized in how to behave think and act will be effective in realizing the goals and ideals of SMA Panca Budi.

\section{School Culture-Based Character Formation Efforts}

Character education is absolutely necessary at school. As already written in the Law of the Republic of Indonesia No. 20 of 2003 It is said that: national education is an education based on Pancasila Indonesia year 1945 that is resourceful on religious values, national culture Response to the demands of the times[11].

The background of the establishment of a superior generation that is beneficial to the environment around the high school Panca Budi Medan focuses on 3 educational services that include:

1. Academic education services focused on the guidance of learning based on the curriculum.

2. A character education service that focuses on planting culture and values to students through routine habituation program every day.

3. The educational service of life skills that comes down to the readiness of learners faces the outside world.

Student character Habituation Program is one way to instill culture and values goodness to students through activities that are finally expected to produce learners who have a noble character that is also characterised by the students The University of Based on the results of observations seen that the planting of culture-based values applied in Senior High School of of Panca Budi Medan is very strong. The most decisive process in seeding the character values of students is the process of habituation.

In the work of habituation, all elements of students, educators and education professionals who are in school are seriously engaged, structured and system. If habituation can be done well, then the values of a culture-based character will be executed properly and without compulsion. The Senior High School of head of Panca Budi Medan has performed the process of habituation of character values to the students continually.

As it has been described earlier that school culture is a set of values that lubricated behaviors, traditions, habits of life, and symbols practiced by the principals, teachers, administrative officers, students and the surrounding community School, and is the hallmark, character or disposition and image of the school in the wider community.
The following is a description of the findings about the school culture that became the frame and base of character formation in Senior High School of Panca Budi Medan as follows:

\section{a. Religious culture}

Religious is a obedient attitude and behavior in carrying out the religious teachings he has adopted, tolerant of the implementation of other religious worship, and living in harmony with the adherents of other religions. The tradition of religiusity in Panca Budi is very condensed by spirituality based on the values to the Tuhanan and humanity which is the main prerequisite to form human believers, science and work through Zikirullah method by adopting 7 basic Values Foundation.

The establishment of religious character manifested in routine program through habituation method in Senior High School of Panca Budi Medan is carried out continuously by various school parties ranging from principals, representatives, teachers, officers and all students. As for the programs/activities religious culture conducted in the Senior High School of Panca Budi Medan, namely: 1) Ahlan wa Sahlan is a welcome greeting to the students before entering the class, 2) prayers Kalicesadyj in congregation at the mosque, 2) The prayers of Dhuhr in congregation in the mosque, 3) program of Practice obligatory Kifayah, 4) Qur'anic thematic program, 5) Islamic Great Day, 6) packing for troubled students through spiritual approach of religion, 7) The practice of 7 basic values of the foundation that imbued all the activities of the school citizen including Senior High School of students Panca Budi.

\section{b. Honest culture}

Honest is a person's attitude when dealing with something by stating the truth and not lying. Being honest become a character that the teacher has used to students in Senior High School of Panca Budi by using behaviorism approach and begins with giving the stimulus of exemplary teacher honest attitude. The consistency of reward and punishment is enforced as part of the effort to cultivate an honest character.

Positive attitude that includes honest behavior is a value that is according to the Senior High School of Panca Budi is seen as the ability of application of positive mental attitude in determining the success of the education process and realize the objectives of Senior High School of education organization Panca Budi. The culture of honesty is familiarize by the teachers for students during learning and testing activities, such as 1) honest in saying the real reason in the late entry class, 2) honest to say the truth if it does not understand the lesson, 3) honest in the task independently, 4) honest in working on the repeated questions and exams. Thus, the stimulus in the form of 
habituation to be honest will result in the honesty responses of the students who become their characters.

\section{c. Clean and energy-efficient culture}

Amidst the problems of the world today that require solving in overcoming the destruction of the environment and the energy crisis, it takes the real action of every human being who lives on this earth to do something so that our earth return to draw, Beautiful and sustainable.

At the University of Panca Budi early learners have been taught to love the environment. The students from Kindergarten, Elementary, Junior High School and Vocational High School, and all the community of Panca Budi Campus together maintain the environment through the implementation program of Clean Culture Civilization (PANDABSIH) and the application of energy efficient culture (BUDABHE).

The culture of living clean and energy saving is a fundamental value and attitude of attention, maintaining and proactive to the conditions or circumstances around us especially in schools. The school as an institution that plays a role in the inheritance of national culture, a place where the nation's children are educated and trained to be good citizens. From the school, it is hoped that the noble duty to be the birth of a clean and energy-saving culture. From school it should be a clean and energy-saving culture started.

Senior High School of Panca Budi, through its education program, has been involved in environmental improvement efforts. The Program of Clean Cultural Civilization (PANDABSIH) and the civilization of Energy saving Cultures (BUDABHE) is an example of the real effort of the school inviting students to love the environment. This clean and energy-saving culture of living has been applied and implemented by teachers, employees, and students in Panca Budi High School even in all divisions and units under the foundation of Prof. Dr. H. Kadirun Yahya including the Panca Budi College.

The activities of the program are sought after the school to cultivate clean and energy-saving life, namely 1) socialization of clean and energy-saving cultural programs by the Committee of the Clean and energy-saving civilization of the foundation in Senior High School of Panca Budi Unit, 2) education through governance Order of cleanliness and energy saving and writing and symbols containing the message about the importance of cleanliness in the form of banners, writing boards, which are displayed in strategic places. 3) habituation to keep the room cleanliness before and after the learning activities through the empowerment of class picket, 4) The activities of the cleaning competition each year, 5) enforcement of fines for anyone who is found to dispose of waste carelessly
School environment, 6) activities of Gotong royong clear the routine environment conducted on every Saturday, 7) environmental education through the provision of a school garden for students to be able to explore their love in the plant. Through the guidance of the teacher, students are taught how to utilize vacant or unmaintained land to be utilized into a powerful plant, 8) The habituation of turning off lights, air conditioning, faucet water after completion of use.

\section{d. Cultural discipline}

Discipline is an act that demonstrates orderly behavior and is obedient to various provisions and rules. A process of education will not succeed if there is no application of discipline to the students. Few schools have managed to run discipline. The fact can be seen through the environment portraits of schools that are not clean, students who love to smoke, and students brawl. All of these mirror behaviors are not disciplined and uncultured. If so happens, school is hard to be the place where generations are well-behaved and accomplished.

Senior High School of Panca Budi is one of the private schools in Medan that is quite famous because of its efficacy. From the beginning, Senior High School of Panca Budi students have been introduced to the school environment that respects and uphold discipline. Panca Budi saw that school discipline is a prerequisite for the creation of an educational environment conducive to educational activities and processes. From this disciplined habituation, the students will get a lot of character values in which they are the character values of responsibility, independent, and the value of the character discipline itself. The activities of the program conducted high school Senior High School of Panca Budi in the cultivation of discipline for students, namely: 1) socialization and recognition of values and culture in the College of Panca Budi especially about sexual education and character development Information about the national insight and insight of the Wiyata Mandala, school discipline, good learning, introduction of school programs, introduction of school facilities, the introduction of school training, the introduction of teachers and education and the transmission of interests and talents through the activities of school environment Introduction (MPLS) 2) enforcement of clear and thorough school order. Obviously the meaning is easy for students to understand, what to do and what is the assumption if it violates. Comprehensively means covering all aspects related to discipline, such as dressing discipline, class-time discipline, learning discipline, rendering discipline on campus. Each point of the order must be socialized in the students, so that they understand why a rule was made, 3 ) the creation of the example from above. In this case, the principal, teacher, and staff are examples of the students ' example. They demonstrate the commitment of their strong discipline with real behavior as outlined in the work culture of the school of Panca Budi, 4) 
extractiveness to students. This is done so that their minds and energies are directed at positive things. The extra-curricular activities provide positive experiences and values for students, who they may not find in teaching and learning activities in the classroom. The school continues to encourage and facilitate students who have talents in a particular field (music, sports, etc.) by facilitating them in participating in competitions at all levels.

\section{The Supporting Factor of Students ' Character Formation in School Culture Based in Senior High School of Panca Budi}

Analysis of supporting factors and inhibiting the formation of character-based school culture in the HIGH School of Panca Budi Medan. In the process of character building based on school culture, there are many obstacles and things that become supporting in the process. The following will be explained about the factors that are supporting and inhibiting the formation of culture-based character in Panca Budi High School, namely:

\section{Supporting Factors}

The factors that support in the process of character building based on school culture are:

a. Family factors (parents)

The role of parents is an important factor to always remind and invite his child to familiarize all good practices that contain the values of character formation in school to always be done when the child is at home. As a parent invites his son to pray in congregation, and the parents always remind the child to say honestly, and familiarize themselves with a clean lifestyle. In addition, parents want to receive any report of good or bad about the development of his son during the learning process in school.

b. Teacher factors

Teacher involvement in character building efforts in high school students Panca Budi is seen in the intensive mentoring of teachers in every activity performed by learners. By providing guidance and direction and transparency, both in the process of learning to teach in the class and after. The mentoring of teachers in each activity is very influential in shaping the character of students in the cultural frame of school. If there is a student behaviour that does not match the values and characters, the teacher will rebuke, and provide direction with the expectations of learners afterwards can immediately improve their behavior.

c. Environmental factors

These environmental factors include the school environment and the community. The school always conducts school environment engineering that is conducive by all staff in the school. As in the implementation, every morning before entering class, the school through the teachers welcomed the arrival of students with a prayer named Ahlan wa Sahlan program. In addition, the school environment is also laid out neatly and cleanly so that it stimulates students to behave in a clean life and does not throw junk. In addition, the community is also a contributing factor in the formation of student characters. Some students are in a community that is in line with the values and cultures gained in the school so that the characters in the students can be easily formed and internalized in daily life.

d. Learners ' factors

The high enthusiasm and curiosity of the learners in understanding the importance of the character value inherent in every good practice and being a culture in school is a positive energy in character building. This situation will turn around if there is no desire of students and what educators and schools have undertaken will feel useless. This can be seen from the enthusiasm of learners while following the learning process in class and participating in every activity outside the classroom that is a culture in the school.

\section{Inhibitory factor}

Some of the inhibitory factors in the formation of cultural-based characters also arise from the same factors of supporting. The factors that impede in the process of establishing a culture-based character at Senior High School of Panca Budi:

a. Family factors

The family factor is primarily an elderly person who is too busy working, so that the supervision and interaction that parents do to the child is increasingly minimal, this causes the good character that is done by the child when in school is less workable in Child's life at home. In this case, the elderly are difficult to become exemplary figures for their children. In addition, there are also families who have fully provided children's education in school without the need to correct or implement the educational values of children's characters when at home. For that, parents should immediately improve their interactions with their children in a better way and demonstrate a gentle attitude to the child.

b. Teacher factors

The role of educators at Senior High School of Panca Budi as a transfer of value occupies the main thing. But there are a still educator who cannot be exemplary in implementing good habits in their daily behavior while in school is an obstacle. Like teachers who do not pray with students in the mosque, teachers who are less concerned with hygiene. It is also 
found that teachers use loud and abusive way when rebuke the wrong learners. So the emotions and patience of educators should be completely laid out, because the pedieners face a lot of students and have a diversity of both in terms of psychology, intelligence and emotion.

c. Environmental factors

Less conducive environmental factors become a barrier in the formation of students ' character and good cultural habituation. The living environment of the learners is partially living housing that is individualist and a free community environment in social relations. In addition, there is an area in the school environment that has not been neatly arranged such as trees that are too far from the leaves to contaminate the area when the leaves fall.

d. Student factors

The cognitive and emotional development of Senior High School of students Panca Budi is an obstacle in the process of character building in the school culture frame. Children who have above average intelligence will readily receive and understand every material and direction provided by educators. So that from this understanding makes it easy for learners to internalize any given material and direction and vice versa. The emotional development of learners who have realized his or her egocentricity has made an obstacle for educators at Senior High School of Panca Budi. This leads to a stunted character formation process, due to the egocentric nature of learners who always wanted to be ahead and wanted to always be noticed by educators, resulting in fights for some learners. Therefore, there needs to be an intense monitoring and thoughtful attitude from educators. In addition, not all student behavior can be detected by educators. Because the number of learners in Senior High School of Panca Budi more than his teachers. Therefore, if there are learners who do some poor attitudes there is nothing that reminds him directly firmly. Based on the explanation above, there is a supporting factor in the establishment of a student-based school culture in Senior High School of Panca Budi. Thus, to reduce these barriers, there is a harmonious synergy of all those who surround the students. It aims to improve the quality of education and so urging the improvement of character for our nation.

\section{CONCLUSIONS AND RECOMMENDATION Conclusions}

From the description of the research on the character formation of school culture based students in Senior High School of Panca Budi can be concluded as follows:

- Senior High School of Panca Budi one of the schools focused on the engineering of educational environment that is inherently with the spirit and the values of Panca Budi is 7 basic values of the foundation in shaping the character of students. Tradition that grows and develops in Senior High School of Panca Budi becomes a culture of school that coloring the quality of school life including the quality of learning, work, environment, interaction of the school citizen and the academic atmosphere that all are not separated from the efforts Value transformation in the character of the students in Senior High School of Panca Budi.

- The character formation efforts of school culture based students include religious culture, honest culture, clean culture and energy saving, and culture discipline. In its implementation, developed through various forms of activities or programs with habituation methods either done routinely or spontaneous, in addition there is an example and mentoring from teachers and school.

- The supporting factor for the establishment of students in Senior High School of Panca Budi is 1) family factors that emphasize the role of parents in strengthening the habituation of behavior for children in the home and community environment; 2) A teacher's factor that focuses on education, mentoring, and the example; 3) Conducive environmental factors so that what is seen, heard, and perceived by the students supports character building. 4) Learners factors that seem to enthusiasm and high curiosity.

- The inhibitory factor of the character formation in Senior High School of Panca Budi is: 1) family factors, occurring in the elderly who are too busy working; 2) Teacher factor, more to educators who have not provided the utmost and not yet maximized in the mentoring to the students; 3) Environmental factors, this occurs in the environment of learners who are partially living in a residential that is individualist and free in association; 4) Student factors, diversity of students ' cognitive development and emotion.

\section{REFERENCES}

1. Agnes, Y. (2012). "Laporan Penelitian Tentang Kenakalan Remaja”, Judul Ilmiah Cara Mengatasi Kenakalan Remaja, Medan, hal Daftar Tabel

2. Said Agil Husein Al Munawar. (2005). Aktualisasi Nilai-Nilai Qur'an, Ciputat: PT Ciputat Press.

3. Novan, A. W. (2012). Pendidikan Karakter dan Kepramukaan. Yogyakarta: Citra Aji Parama.

4. Endah, S. (2012). Impelementasi Pendidikan Karakter di Sekolah, Yogyakarta: PT Citra Aji Parama

5. Aan Komariyah, Cepi Triatna. (2005). Visionary Leadership Menuju Sekolah Efektif. Jakarta: Bumi Aksara. 
6. John, W. Creswell. (2015). Penelitian Kualitatif \& Desain Riset, Memilih di Antara Lima Pendekatan, and Yogyakarta: Pustaka Pelajar.

7. Robert Bogdan dan Steven J. (1992). Taylor, Pengantar Metodologi Penelitian Kualitatif Studi Pendekatan Fenomenologis Terhadap Ilmu Sosial, terj. Arif Rahman, Surabaya: Usaha Nasional. Bandingkan dengan: Lexy J. Moelong, 2002, Metode Penelitian Kualitatif, Rosda Karya: Bandung
8. Fraenkel. (2012). How To Design and Evaluate Research in Education, New York: McGraw Hill.

9. Nurul, Z. (2009). Metodologi Penelitian Sosial dan Pendidikan, Jakarta: Bumi Aksara,

10. Suharsimi, A. (1993). Prosedur Penelitian, Suatu Pendekatan Praktek, Jakarta: Rineka Cipta.

11. Iskandar, A. (2011). Pendidikan Membangun Karakter Bangsa, Jakarta: Bestari Muana Murni. 